\title{
Local Price Variation and Labor Supply Behavior
}

\author{
Dan A. Black, Natalia A. Kolesnikova, and Lowell J. Taylor
}

\begin{abstract}
In standard economic theory, labor supply decisions depend on the complete set of prices: wages and the prices of relevant consumption goods. Nonetheless, most theoretical and empirical work in labor supply studies ignore prices other than wages. We address the question of whether the common practice of ignoring local price variation in labor supply studies is as innocuous as generally assumed. We describe a simple model to demonstrate that the effects of wage and nonlabor income on labor supply typically differ by location. In particular, we show that the derivative of the labor supply with respect to nonlabor income is independent of price only when the labor supply takes a form based on an implausible separability condition. Empirical evidence demonstrates that the effect of price on labor supply is not a simple "up-or-down shift" that would be required to meet the separability condition in our key proposition. (JEL J01, J21, R23)
\end{abstract}

Federal Reserve Bank of St. Louis Review, 2009, 91(6), pp. 613-25.

n standard economic theory, labor supply decisions depend on the complete set of prices: the wages and the prices of relevant consumption goods. Nonetheless, as Abbott and Ashenfelter (1976) noted some 30 years ago, economists generally have found it a useful abstraction, in both theoretical and empirical work, to ignore prices other than wages in labor supply studies. For example, none of the empirical results on labor supply discussed in the prominent reviews of Pencavel (1986), Killingsworth and Heckman (1986), or Blundell and MaCurdy (1999) are derived by procedures that account for variation in any price other than wages. ${ }^{1}$

However, most empirical work on labor does use national datasets of individuals who live in different locations and therefore face different prices for locally priced goods. These price differences can be quite large, especially for housing. For example, according to 1990 Census data, the median housing price in New York is more than three times that of the median housing price in Cleveland. ${ }^{2}$ The question addressed in this paper is whether the common practice of ignoring local price variation in labor supply studies is as innocuous as has generally been assumed.

To examine the issue, we first present a simple theoretical model: an economy in which people live in different locations with differing levels of a production or consumption amenity. Following

1 Abbott and Ashenfelter's (1976) evaluation of labor supply in the United States for the 1929-67 period exploits time-series changes in relative prices but does not evaluate possible impacts of crosssectional variation (which, as they state, is "expected to be small"). Some work conducts sensitivity analysis using Bureau of Labor Statistics information on the cost of living to "adjust" wages. See, for instance, DaVanzo, DeTray, and Greenberg (1973) and Masters and Garfinkel (1977).

2 Gabriel and Rosenthal (2004) and Chen and Rosenthal (2008) show that massive housing price differences pertain across cities even after careful adjustment for quality.

Dan A. Black is a professor in the Harris School, University of Chicago, and a senior fellow at the National Opinion Research Center; Natalia A. Kolesnikova is an economist at the Federal Reserve Bank of St. Louis; and Lowell J. Taylor is a professor of economics at the Heinz College, Carnegie Mellon University. An earlier version of this article was published in the Federal Reserve Bank of St. Louis Regional Economic Development, 2008, 4(1), pp. 2-14.

(C) 2009, The Federal Reserve Bank of St. Louis. The views expressed in this article are those of the author(s) and do not necessarily reflect the views of the Federal Reserve System, the Board of Governors, or the regional Federal Reserve Banks. Articles may be reprinted, reproduced, published, distributed, displayed, and transmitted in their entirety if copyright notice, author name(s), and full citation are included. Abstracts, synopses, and other derivative works may be made only with prior written permission of the Federal Reserve Bank of St. Louis. 
logic familiar in urban economics, (e.g., Roback, 1982), equilibrium prices will differ across locations. We demonstrate that labor supply behavior also can vary across locations.

Next, we demonstrate that, when prices vary across locations, local variation in prices can be safely ignored only when preferences take a very specific and peculiar form. We also show that the responsiveness of labor supply to wage changes will be the same across locations only if the responsiveness of labor supply to nonlabor income changes is the same across locations.

In our third step we evaluate the potential empirical importance of our theoretical observations. We present results obtained by using 1990 Public Use Microdata Samples (PUMS) of the 1990 U.S. Census that examine labor supply in the nation's 50 largest cities. We focus on the labor force participation and hours decisions of white married women aged 30 to 50-a group whose labor decisions are quite responsive to changes in wages and nonlabor income.

In general, we analyze the basic "building block" empirical relationship that would underlie any empirical analysis of labor supply for this group: the relationship between nonlabor income and labor supply. Our innovation is examining this relationship for each of the 50 cities separately and demonstrating the significant systematic variation that exists among them.

We find that the basic correlation-between labor supply and nonlabor income-differs across cities. For example, women who have relatively high nonlabor income (primarily a husband's income) work relatively fewer hours and have lower participation rates. An important observation, from our perspective, is that this anticipated negative relationship is substantially more pronounced in cities with inexpensive housing than in cities with expensive housing.

\section{A MODEL OF LOCAL LABOR MARKETS WITH STONE-GEARY PREFERENCES}

We begin our study by presenting a simple model of local price variation along the lines of
Roback (1982) and Haurin (1980). Locations differ based on two criteria: (i) A location may be inherently more pleasant (i.e, have a higher level of a "consumption amenity," such as nice weather), or (ii) a location may be associated with inherently higher productivity (e.g., owing to the presence of a natural resource or an agglomeration of economies in production). For simplicity we restrict attention to cases in which people choose to live in one of two cities.

In contrast to the standard urban location models such as those of Roback (1982) or Haurin (1980), which fix labor supply as a constant, we allow labor supply to be a choice variable. Preferences are assumed to be Stone-Geary. This is a particularly transparent form of utility, and as Ashenfelter and Ham (1979) note, it is the simplest functional form of utility used in applied empirical work examining labor supply. ${ }^{3}$ We assume, in particular, that individual $i$ has utility $u^{i}$ as a function of a consumption good $x$, leisure $l$ (which is scaled so that $0 \leq l \leq 1$ ), and an amenity level $A^{j}$ (that is specific to location $j$ ), according to a simple Stone-Geary form as follows:

$$
u^{i}=\theta^{i j} A^{j}(x-c)^{\delta} 1^{1-\delta},
$$

where $c$ and $\delta$ are parameters that are common across individuals and $\theta^{i j}$ is a positive idiosyncratic parameter that equals 1 for a typical individual, but allows for the possibility that person $i$ has a particular attraction, or distaste, for location $j$ (as $\theta^{i j}$ is greater than, or less than, 1).

A person living in location $j$ maximizes utility subject to a budget constraint, $p_{j} x=w_{j}(1-l)+N$, where $p_{j}$ is the price for the local consumption good, $w_{j}$ is the local wage, and $N$ is nonlabor income. Assuming an interior solution pertains, demand for leisure and for the consumption good are, respectively,

$$
l\left(w_{j}, p_{j}\right)=\frac{(1-\delta)\left(N+w_{j}-c p_{j}\right)}{w_{j}},
$$

and

\footnotetext{
3 See also Blundell and MaCurdy (1999) for a discussion of the Stone-Geary form, as well as other forms used in applied work on labor supply.
} 


$$
x\left(w_{j}, p_{j}\right)=\frac{\delta\left(N+w_{j}-c p_{j}\right)}{p_{j}}+c .
$$

Substituting equations (2) and (3) into equation (1) gives indirect utility for person in location

$$
V^{i j}=\frac{\theta^{i j} A^{j} \delta^{\delta}(1-\delta)^{1-\delta}\left(N+w_{j}-c p_{j}\right)}{p_{j}^{\delta} w_{j}^{1-\delta}} .
$$

In equilibrium each individual chooses to live in the location that yields the highest level of utility. There are two locations: $j=1$ or 2 . We present two cases: one with differing consumption amenities and one with differing levels of productivity in the locations.

\section{Case 1: Differing Levels of the Consumption Amenity}

Suppose there is general agreement that Location 1 is nicer than Location $2, A^{1}>A^{2}$, and for the moment assume further that there are no idiosyncratic differences in opinion about location, so that $\theta^{i j}=1$ for all individuals. Because workers are equally productive in the two locations, wages and $w_{1}$ and $w_{2}$ must be the same, say $w^{4}$ In an equilibrium in which people live in both locations, we must have $V^{i 1}=V^{i 2}$, so using equation (4), it is clear that $p_{1}$ and $p_{2}$ must solve

$$
\frac{A^{1}\left(N+w-c p_{1}\right)}{p_{1}^{\delta} w^{1-\delta}}=\frac{A^{2}\left(N+w-c p_{2}\right)}{p_{2}^{\delta} w^{1-\delta}} .
$$

Inspection of equation (5) confirms the intuitive result that $p_{1}>p_{2}$ : The local consumption good is more expensive in Location 1-the high-amenity city.

This logic continues to hold if we add back the idiosyncratic taste component to utility. If for the marginal individual $\theta^{i 1}=\theta^{i 2}=1$, equation (5) still characterizes equilibrium prices. In this instance, however, some individuals will have a

\footnotetext{
4 For simplicity, we are implicitly assuming that labor is the only factor of production, so that firms will be indifferent in hiring if the wage is the same in the two cities. This would not be true, for example, if land were a major factor of production and land prices differed in the two cities.
}

strict preference with regard to location. For example, an individual with $\theta^{i 1}>\theta^{i 2}$ will have a strict preference for Location 1 over Location 2.

We turn next to labor supply. Let $h$ be the fraction of time that a person works, $h=1-l$. From equation (2), we have

$$
h\left(w, p_{j}\right)=\frac{\delta w-(1-\delta)\left(N-c p_{j}\right)}{w} .
$$

Although wages are the same in both locations, the labor supply differs. In this example, $h\left(w, p_{1}\right)$ $>h\left(w, p_{2}\right)$; individuals supply more labor when they work in the more expensive city.

Suppose instead the focus is on the effect of a wage change in a local labor market (studying people who would not move in response to a small change in the wage) ${ }^{5}$ :

$$
\frac{\partial h\left(w, p_{j}\right)}{\partial w}=\frac{(1-\delta)\left(N-c p_{j}\right)}{w^{2}} .
$$

Notice that in this example, the responsiveness of the labor supply to a wage change is greater in the inexpensive city than in the expensive city,

$$
\frac{\partial h\left(w, p_{2}\right)}{\partial w}>\frac{\partial h\left(w, p_{1}\right)}{\partial w} .
$$

In contrast, if we focus on how a change in nonlabor income affects labor supply,

$$
\frac{\partial h\left(w, p_{j}\right)}{\partial N}=\frac{-(1-\delta)}{w},
$$

we find that the relationship is independent of the local price; that is, it can be written as

$$
\frac{\partial h(w)}{\partial N} .
$$

\section{Case 2: Differing Levels of Productivity}

Now suppose that Locations 1 and 2 are viewed as equally pleasant, $A^{1}=A^{2}$, but productivity is higher in Location 1 than in Location 2 ,

\footnotetext{
5 In general, if the wage increases in a labor market, this factor can attract new individuals to that location. Here, we are interested in the effect on the labor supply of individuals who are already in the market, for example, people who have an idiosyncratic taste for that location.
} 
so that $W_{1}>w_{2}$. The equilibrium condition corresponding to equation (5) - that the marginal individual is indifferent between locations (i.e., $V^{i 1}=V^{i 2}$ )—is then

$$
\frac{\left(N+w_{1}-c p_{1}\right)}{p_{1}^{\delta} w_{1}^{1-\delta}}=\frac{\left(N+w_{2}-c p_{2}\right)}{p_{2}^{\delta} w_{2}^{1-\delta}} .
$$

As for labor supply, in city $j$,

$$
h\left(w_{j}, p_{j}\right)=\frac{\delta w_{j}-(1-\delta)\left(N-c p_{j}\right)}{w_{j}} .
$$

In general, labor supply differs in the two locations, but even with $p_{1}>p_{2}$ and $w_{1}>w_{2}$ the location that will have the larger labor supply cannot be predicted. Similarly, in general

$$
\frac{\partial h\left(w_{1}, p_{1}\right)}{\partial w} \neq \frac{\partial h\left(w_{2}, p_{2}\right)}{\partial w},
$$

and we cannot determine in which city the labor supply is more responsive to wage changes. On the other hand, in this example the derivative of labor supply with respect to nonlabor income,

$$
\frac{\partial h\left(w_{j}, p_{j}\right)}{\partial N}=\frac{-(1-\delta)}{w_{j}},
$$

turns out to be independent of $p_{j}$. Furthermore, the derivative of labor supply with respect to nonlabor income does not depend on the local price, $p$, but because in equilibrium the highproductivity city has relatively higher wages, we expect to observe that $\delta h / \delta N$ will be smaller (in absolute value) in the expensive city.

Our examples illustrate two important points. First, cross-sectional variation in wages and prices may be associated with variation in labor supply, although that cross-sectional variation is of no value for understanding the behavioral effect of wage changes on labor supply. For instance, in our Case 2, even if in both cities

$$
\frac{\partial h\left(w_{j}, p_{j}\right)}{\partial w}>0,
$$

identical individuals may well supply less labor in the high-wage city than in the low-wage city, depending on the local price-wage combination. Second, the responsiveness of labor supply to changes in the wage or nonlabor income typically varies across locations.

\section{WHEN DOES PRICE VARIATION MATTER FOR LOCAL LABOR SUPPLY?}

As noted previously, housing prices vary widely across U.S. cities, presumably because of differences in consumption or production amenities across these locations. The examples in the previous section indicate that labor supply varies across locations even in the unusually simple and transparent case of Stone-Geary preferences. We now turn to a more systematic investigation of conditions on preferences under which price and income effects on labor supply do not depend on location. As is common in the literature, attention is restricted to the case of quasi-homothetic preferences (of which Stone-Geary is a special case). ${ }^{6}$ Given this common simplification, what further restrictions are necessary to allow investigators to ignore variation across locations when examining labor supply?7

Under quasi-homothetic preferences, indirect utility takes the form

$$
V(p, w, N)=\alpha(p, w)+(N+w) \beta(p, w),
$$

where, as before, $p$ is the local price, $w$ is the local wage, and $N$ is the nonlabor income. Using Roy's identity we derive the demand for leisure

\footnotetext{
6 Quasi-homothetic preferences are useful because they preserve a linear expansion path of homothetic preferences, but they do not require the path to go through the origin. Thus, under quasihomothetic preferences, income elasticities of demand need not equal 1, as is the case with homothetic preferences.

7 We could attempt to analyze cases that are even more general, but as we shall see, matters are sufficiently discouraging even for the quasi-homothetic case.
} 


$$
\begin{aligned}
& I(p, w, N)-1=-\frac{\partial V / \partial w}{\partial V / \partial N} \\
& =-\frac{\alpha_{w}(p, w)+\beta(p, w)+(N+w) \beta_{w}(p, w)}{\beta(p, w)} \\
& =-\frac{\alpha_{w}(p, w)+(N+w) \beta_{w}(p, w)}{\beta(p, w)}-1, \\
& I(p, w, N)=-\frac{\alpha_{w}(p, w)+(N+w) \beta_{w}(p, w)}{\beta(p, w)} .
\end{aligned}
$$

It then follows that hours of labor supply are

$$
\begin{aligned}
h(p, w, N) & =1-l(p, w, N) \\
& =1+\frac{\alpha_{w}(p, w)+(N+w) \beta_{w}(p, w)}{\beta(p, w)}: \\
& =a(p, w)+(N+w) b(p, w),
\end{aligned}
$$

where $a(p, w)=1+\frac{\alpha_{w}}{\beta}, b(p, w)=\frac{\beta_{w}}{\beta}$.

Consider the effect of the change in nonlabor income on the labor supply,

$$
\frac{\partial h}{\partial N}=b(p, w)=\frac{\beta_{w}(p, w)}{\beta(p, w)} .
$$

Obviously, $\delta h / \delta N$ is independent of $p$ (and thus is the same across locations) if and only if $b(p, w)$ $\equiv b(w)$. The following claim provides the condition under which this holds:

$\operatorname{Claim} \frac{\beta_{w}(p, w)}{\beta(p, w)}=b(w) \Leftrightarrow \beta(p, w)=\beta_{1}(p) \beta_{2}(w)$.

Proof. The proof of sufficiency is trivial. To prove necessity, we have

$$
\begin{aligned}
\frac{\beta_{w}(p, w)}{\beta(p, w)} & =b(w), \\
\frac{\partial}{\partial w} \ln \beta(p, w) & =b(w), \\
\ln \beta(p, w) & =\int_{b(w) d w+c(p),} \\
\beta(p, w) & =e^{\int_{b(w) d w+c(p)}}=\beta_{1}(p) \beta_{2}(w),
\end{aligned}
$$

where $\beta_{2}(w)=e^{\int b(w) d w}$.
The above observations can be summarized as follows:

Proposition 1 When preferences are quasihomothetic,

$$
\frac{\partial h}{\partial N}
$$

is independent of location if and only if preferences satisfy a separability condition $\beta(p, w)=\beta_{1}(p) \beta_{2}(w)$.

Next consider the response of the demand for leisure to wage changes,

$$
\frac{\partial h}{\partial w}=a_{w}(p, w)+b(p, w)+(N+w) b_{w}(p, w) .
$$

Again, the goal is to derive conditions under which

$$
\frac{\partial h}{\partial w}
$$

does not depend on local prices, $p$. If $b(p, w)=b(w)$, as above, then the only other necessary condition is that $a_{w}(p, w)$ be independent of $p$. Now $a_{w}(p, w)$ is independent of $p$ if and only if it is equal to some function of $w$ only: $a_{w}(p, w)=f(w)$. Integrating both parts with respect to $w$, we get $a(p, w)=F(w)+c(p)$. Then the supply of hours of work takes an additively separable form, $h(p, w, N)=c(p)+F(w)+$ $(N+w) b(w)$.

We have established, therefore,

Proposition 2 When preferences are quasihomothetic,

$$
\frac{\partial h}{\partial w} \text { and } \frac{\partial h}{\partial N}
$$

are independent of location if and only if the demand for leisure has the additively separable form

$$
h(p, w, N)=c(p)+F(w)+(N+w) b(w) .
$$

Notice that in equation (15) the effect of local price variation is to simply shift the labor supply function up or down. In this case, it might suffice to merely incorporate location-specific dummies when estimating labor supply functions. ${ }^{8}$ Without this separability, however, local price variation would have a fundamental impact on the shape of the labor supply function itself.

8 In fact, in empirical work on labor supply, researchers generally do not even take this simple step. 
These two propositions demonstrate that even in the simple case of quasi-homothetic preferences, rather strong conditions are necessary for location-independent labor supply responses to income and wage changes.

The Stone-Geary example used in the previous section illustrates this point. Indirect utility can be written in the form $V=\alpha(p, w)+(N+w) \beta(p, w)$, where

$$
\begin{aligned}
\alpha(p, w) & =-\frac{c p \theta A \delta^{\delta}(1-\delta)^{1-\delta}}{p^{\delta} w^{1-\delta}} \\
& =-c p^{1-\delta} \theta A \delta^{\delta}(1-\delta)^{1-\delta} \cdot \frac{1}{w^{1-\delta}}, \\
\beta(p, w) & =\frac{\theta A \delta^{\delta}(1-\delta)^{1-\delta}}{p^{\delta} w^{1-\delta}} \\
& =\frac{\theta A \delta^{\delta}(1-\delta)^{1-\delta}}{p^{\delta}} \cdot \frac{1}{w^{1-\delta}} .
\end{aligned}
$$

Since $\beta(p, w)$ is separable in $p$ and $w$, the separability condition of Proposition 1 is satisfied. Recall from equation (6) that

$$
h(p, w, N)=\frac{\delta w-(1-\delta)(N-c p)}{w} .
$$

Obviously, this function does not have an additively separable form as required in Proposition 2. So it is not surprising that the derivative of labor supply with respect to nonlabor income, $N$,

$$
\frac{\partial h}{\partial N}=-\frac{(1-\delta)}{w},
$$

is independent of $p$, whereas the derivative of leisure with respect to the wage, $w$,

$$
\frac{\partial h}{\partial w}=\frac{(1-\delta)(N-c p)}{w^{2}},
$$

depends on $p$.

As noted earlier, labor supply studies generally focus on the responsiveness of labor supply to changes in wages. Here, we want to evaluate how price variations, in addition to changes in wages, affect the results. The ideal experiment would be one in which wages are exogenously shifted in each of many different U.S. cities and in which changes in labor supplied in each city can be traced. Finding data that correspond to such an experiment is a formidable task. The following work instead focuses exclusively on the sensitivity of labor supply to nonlabor income. We can justify this focus with the following result:

Proposition 3 In general, labor supply, $h(p, w, F)$, depends on the price of the local good, the wage, and full income, $F=w+N .^{9}$

If the key relationship $\frac{\partial h}{\partial w}$ is independent of $p$,

then $\frac{\partial h}{\partial N}$ is independent of $p$.

To prove this proposition we consider first the effect of a change in nonlabor income on labor supply:

$$
\frac{\partial h(p, w, F)}{\partial N}=\frac{\partial h(p, w, F)}{\partial F} \cdot \frac{\partial F}{\partial N}=\frac{\partial h(p, w, F)}{\partial F} .
$$

This is independent of price, $p$, if and only if

$$
\frac{\partial h(p, w, F)}{\partial F}=G(w, F) .
$$

Integrating both sides of equation (18), we then notice that labor supply must have the following additively separable form:

$$
\begin{aligned}
h(p, w, F) & =g(w, F)+c(p, w) \\
& =g(w, w+N)+c(p, w) .
\end{aligned}
$$

Similarly, the effect of the change in the wage on labor supply does not depend on $p$ if and only if

$$
\frac{\partial h(p, w, F)}{\partial w}=Q(w, F),
$$

or, integrating both sides of equation (20),

$$
\begin{aligned}
h(p, w, F) & =q(w, F)+k(p) \\
& =q(w, w+N)+k(p) .
\end{aligned}
$$

Compare the additive separability requirements shown in equations (19) and (21). The latter takes the same basic form but is more restrictive. It follows that when

\footnotetext{
9 Recall that full-time work entails $h=1$, so that the maximum possible labor income is $w+N$, making full income.
} 


$$
\begin{aligned}
& \frac{\partial h}{\partial w} \text { is independent of the local price, } p \\
& \frac{\partial h}{\partial N} \text { is independent of the local price, } p \text {. }
\end{aligned}
$$

\section{EMPIRICAL RESULTS}

The theoretical considerations outlined in the preceding section suggest that unless preferences are strongly restricted, the responsiveness of labor supply to nonlabor income and to the wage will vary across locations. It is possible, of course, that the differences are insignificant and do not pose a problem for empirical work. We examine this possibility using a dataset of married white women-a group that is likely to have substantial variation in labor supply (e.g., in response to differences in wage, nonlabor income, and possibly local prices). Data used in the analysis are from the 1990 PUMS $^{10}$; data include married non-Hispanic white women, aged 30 to 50, who live in the 50 largest metropolitan statistical areas (MSAs) in the United States.

One goal of this exploration is to see if there are any systematic differences in labor supply related to differences in local prices. We consider the relationship between labor supply and nonlabor income; the latter term is defined as family income minus the woman's own total income. Given previous research on married women's labor supply, an inverse relationship would be expected between nonlabor income and labor supply (i.e., leisure is likely a "normal good.") The question here is whether that relationship differs in a systematic way across cities.

Examining the relationship between nonlabor income and married women's labor supply in cross section is far from "state of the art" in estimating labor supply. Still, it seems a reasonable first pass at the issue, especially given that our focus is not on any estimated relationship per se but on differences in the relationships in expensive and inexpensive urban areas.

In our investigation of the differences in the response of labor supply to the change in nonla-

\footnotetext{
${ }^{10}$ Data were provided by the Minnesota Population Center (Ruggles et al., 2008).
}

bor income, we do not want to specify any parametric form because of concerns that results might be sensitive to the functional form. ${ }^{11}$ Instead, we use a nonparametric matching estimator. Two measures of labor supply are used: annual hours of work and an employment participation dummy variable. ${ }^{12}$ The data do not allow us to perform this analysis for each city because they do not provide enough support. Instead, we divide the sample roughly into thirds and examine differences between the most "expensive" cities (the 17 MSAs within the top one-third of housing prices) and "inexpensive" cities (the 17 MSAs with the lowest housing prices).

Our comparison of married women's labor supply in inexpensive and expensive cities then follows three additional steps. The first step is to divide households into deciles according to "nonlabor income" (which is predominately the husband's income). Then within each decile we compare the labor supply of women who live in the expensive cities relative to the labor supply of women who live in inexpensive cities. The goal is to compare the labor supply of otherwise similar women, so we use an estimator that matches women with exactly the same age and level of education. Separate analyses also are conducted for women with high school education and college education. Thus, the second step is to match women living in an expensive city with corresponding women living in inexpensive cities (i.e., we match women in each nonlabor income decile, $d_{i}(i=1, \ldots, 10)$, with age and education vector $x=X$, to women with these same characteristics living in inexpensive cities). In the analysis that centers on annual work hours, this is

$$
\Delta\left(X, d_{i}\right)=E\left(h_{1} \mid x=X, d_{i}\right)-E\left(h_{0} \mid x=X, d_{i}\right),
$$

where $h_{1}, h_{0}$ are annual hours of work in expensive and inexpensive cities, respectively. In the absence of selection, this might be taken to be the causal effect on labor supply (measured in hours per year) of living in an expensive city relative to

\footnotetext{
${ }^{11}$ See, for example, DaVanzo, DeTray, and Greenberg (1973).

${ }^{12}$ We also repeated the analysis with several other measures of labor force participation, such as an indicator of full-time employment. The results remain essentially the same.
} 


\section{Table 1}

\section{Differences in Annual Hours and Participation Rates Between Expensive and Inexpensive Locations by Nonlabor Income Deciles}

\begin{tabular}{|c|c|c|c|c|c|c|}
\hline \multirow[b]{2}{*}{ Nonlabor income decile } & \multicolumn{2}{|c|}{ All women } & \multicolumn{2}{|c|}{$\begin{array}{l}\text { Women with a } \\
\text { high school diploma }\end{array}$} & \multicolumn{2}{|c|}{$\begin{array}{l}\text { Women with a } \\
\text { college degree }\end{array}$} \\
\hline & $\begin{array}{l}\text { Change in } \\
\text { annual } \\
\text { hours }\end{array}$ & $\begin{array}{l}\text { Change in } \\
\text { participation } \\
\text { rates }\end{array}$ & $\begin{array}{l}\text { Change in } \\
\text { annual } \\
\text { hours }\end{array}$ & $\begin{array}{c}\text { Change in } \\
\text { participation } \\
\text { rates }\end{array}$ & $\begin{array}{l}\text { Change in } \\
\text { annual } \\
\text { hours }\end{array}$ & $\begin{array}{c}\text { Change in } \\
\text { participation } \\
\text { rates }\end{array}$ \\
\hline 1 & $\begin{array}{r}-117.34 \\
(14.23)\end{array}$ & $\begin{array}{l}-0.04 \\
(0.0065)\end{array}$ & $\begin{array}{l}-136.1 \\
(24.57)\end{array}$ & $\begin{array}{l}-0.04 \\
(0.012)\end{array}$ & $\begin{array}{l}-78.08 \\
(34.88)\end{array}$ & $\begin{array}{l}-0.02 \\
(0.016)\end{array}$ \\
\hline 2 & $\begin{array}{c}-75.46 \\
(14.32)\end{array}$ & $\begin{array}{l}-0.01 \\
(0.0063)\end{array}$ & $\begin{array}{c}-75.72 \\
(24.36)\end{array}$ & $\begin{array}{l}0.00 \\
(0.011)\end{array}$ & $\begin{array}{c}-99.43 \\
(36.47)\end{array}$ & $\begin{array}{c}-0.02 \\
(0.016)\end{array}$ \\
\hline 3 & $\begin{array}{c}-54.14 \\
(13.74)\end{array}$ & $\begin{array}{l}-0.01 \\
(0.0060)\end{array}$ & $\begin{array}{c}-19.42 \\
(23.39)\end{array}$ & $\begin{array}{l}0.00 \\
(0.012)\end{array}$ & $\begin{array}{l}-46.71 \\
(33.98)\end{array}$ & $\begin{array}{l}-0.01 \\
(0.015)\end{array}$ \\
\hline 4 & $\begin{array}{c}-15.14 \\
(13.88)\end{array}$ & $\begin{array}{l}0.00 \\
(0.0062)\end{array}$ & $\begin{array}{c}-28.97 \\
(23.63)\end{array}$ & $\begin{array}{l}-0.01 \\
(0.012)\end{array}$ & $\begin{array}{c}-20.59 \\
(37.16)\end{array}$ & $\begin{array}{l}0.00 \\
(0.016)\end{array}$ \\
\hline 5 & $\begin{array}{c}-20.68 \\
(13.31)\end{array}$ & $\begin{array}{c}0.01 \\
(0.0063)\end{array}$ & $\begin{array}{c}-51.79 \\
(24.14)\end{array}$ & $\begin{array}{c}0.00 \\
(0.012)\end{array}$ & $\begin{array}{c}-13.31 \\
(34.57)\end{array}$ & $\begin{array}{c}0.03 \\
(0.015)\end{array}$ \\
\hline 6 & $\begin{array}{c}2.59 \\
(13.66)\end{array}$ & $\begin{array}{l}0.02 \\
(0.0068)\end{array}$ & $\begin{array}{c}-39.52 \\
(24.14)\end{array}$ & $\begin{array}{c}0.00 \\
(0.013)\end{array}$ & $\begin{array}{c}59.98 \\
(31.66)\end{array}$ & $\begin{array}{l}0.05 \\
(0.015)\end{array}$ \\
\hline 7 & $\begin{array}{c}12.47 \\
(14.38)\end{array}$ & $\begin{array}{l}0.01 \\
(0.0072)\end{array}$ & $\begin{array}{c}-16.11 \\
(24.79)\end{array}$ & $\begin{array}{c}0.00 \\
(0.013)\end{array}$ & $\begin{array}{c}85.6 \\
(30.99)\end{array}$ & $\begin{array}{c}0.03 \\
(0.015)\end{array}$ \\
\hline 8 & $\begin{array}{c}83.55 \\
(14.62)\end{array}$ & $\begin{array}{l}0.05 \\
(0.0076)\end{array}$ & $\begin{array}{c}81.95 \\
(26.78)\end{array}$ & $\begin{array}{l}0.05 \\
(0.014)\end{array}$ & $\begin{array}{l}139.38 \\
(30.24)\end{array}$ & $\begin{array}{l}0.08 \\
(0.015)\end{array}$ \\
\hline 9 & $\begin{array}{c}83.61 \\
(15.80)\end{array}$ & $\begin{array}{l}0.04 \\
(0.0083)\end{array}$ & $\begin{array}{c}88.98 \\
(33.44)\end{array}$ & $\begin{array}{c}0.03 \\
(0.017)\end{array}$ & $\begin{array}{c}128.59 \\
(30.84)\end{array}$ & $\begin{array}{l}0.06 \\
(0.016)\end{array}$ \\
\hline 10 & $\begin{array}{c}82.59 \\
(18.45)\end{array}$ & $\begin{array}{l}0.04 \\
(0.0098)\end{array}$ & $\begin{array}{c}15.74 \\
(41.52)\end{array}$ & $\begin{array}{l}0.00 \\
(0.023)\end{array}$ & $\begin{array}{l}172.35 \\
(28.04)\end{array}$ & $\begin{array}{l}0.07 \\
(0.015)\end{array}$ \\
\hline
\end{tabular}

NOTE: Authors' calculations, based on 5 percent 1990 PUMS data. The sample consists of white, non-Hispanic married women, aged 30 to 50 . Bootstrapped standard errors using 999 replications are reported in parentheses.

an inexpensive city. The third step is to average the quantity in equation (22) across all women in each decile $d_{i}$ :

$$
\Delta_{n}\left(d_{i}\right)=\int \Delta\left(x \mid d_{i}\right) d F_{n}(x \mid i),
$$

where $d F_{n}\left(x \mid d_{i}\right)$ is the national distribution of $x$ in the decile $d_{i}$.

The analysis is repeated using a second measure of labor supply-a labor force participation dummy variable. When these empirical exercises are performed separately for women with a high school diploma and those with a college degree, $x$, is simply an age vector.

Results are reported in Table 1. The difference in annual hours of work between women living in expensive and inexpensive cities is substantial (and statistically significant) for many of the nonlabor income deciles. For example, ninth-decile women in expensive cities work considerably longer hours than corresponding women in inexpensive cities. College-educated women in this decile average 129 more work hours, whereas women with a high school education work an average of 89 hours more.

An apparent and striking pattern is shown in Table 1 and Figure 1. First, as might be expected, among these married women, leisure appears to be a normal good; women with higher levels of outside income generally work fewer hours per year and have lower labor force participation rates. 


\section{Figure 1}

Variation Between Expensive and Inexpensive Locations in Annual Hours and Participation Rates, by Nonlabor Income Decile
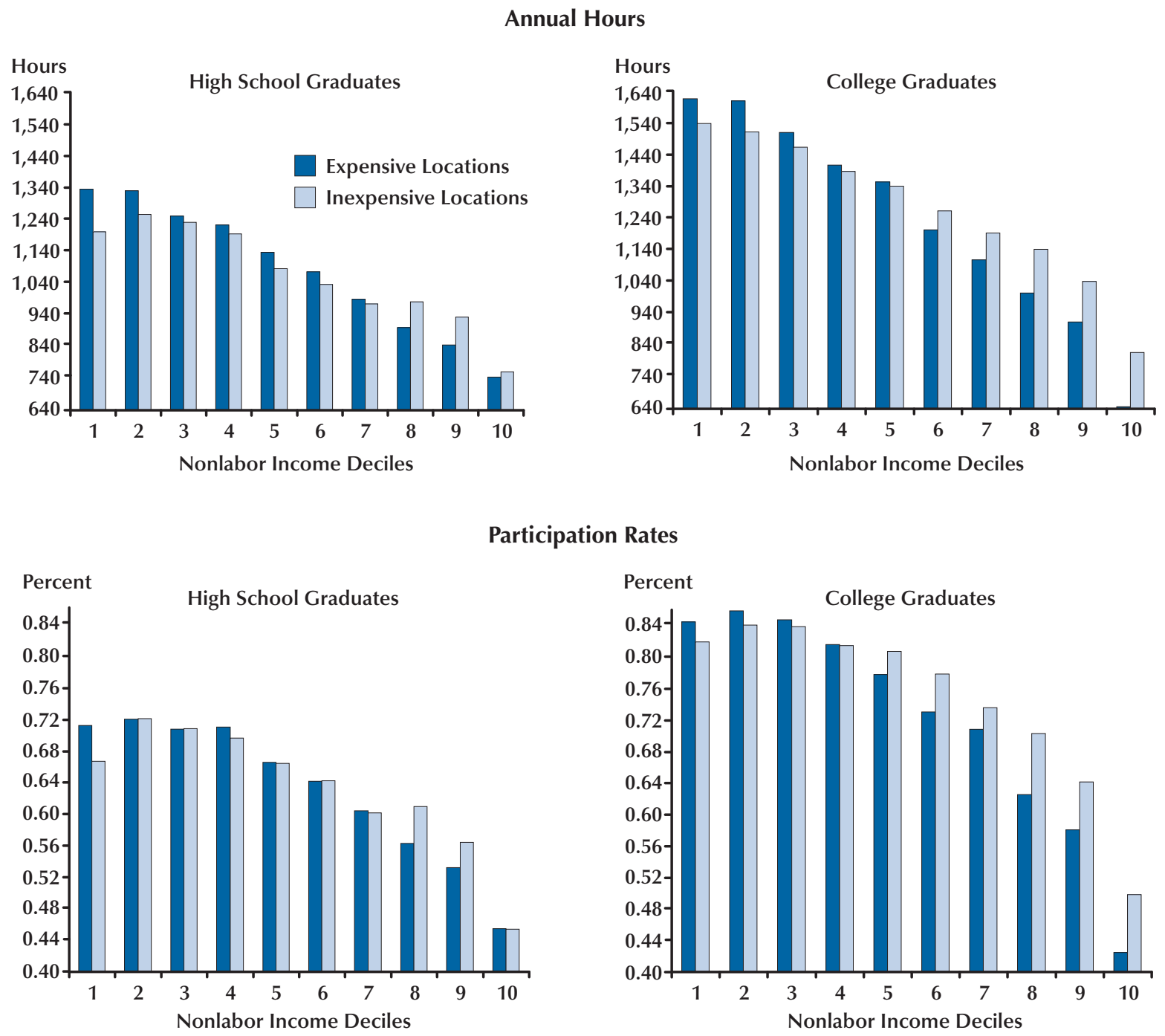

More important, for our purposes, is that the relationship between nonlabor income and labor supply is quite different for expensive and inexpensive cities. At the very lowest levels of nonlabor income (e.g., deciles 1 and 2), women in expensive cities have lower labor supply than women in inexpensive cities. The opposite is essentially true for women in the high nonlabor income deciles; among women with high nonlabor income, labor force participation and average hours worked are higher in expensive cities than in inexpensive cities.

In short, the labor/leisure choice appears to not conform to the additively separable form described in Proposition 2; local prices do not merely shift labor supply up or down. The derivative

$$
\frac{\partial h}{\partial N}
$$


is generally negative (at least beyond the lowest decile levels of $N$ ) and is smaller (in absolute value) in the expensive city. This generalization holds true for both high school- and collegeeducated women.

Also, as noted, results are similar when "average hours" or "labor force participation rates" are used as the measure of labor supply. Of note, in these cities 66 percent of high school-educated women and 70 percent of college-educated women are employed on average. Thus, differences of 5 to 7 percentage points between expensive and inexpensive cities represent differentials of 8 to 10 percent, which seem (to us) quite substantial.

Our nonparametric approach does have one disadvantage: The nonlabor income distribution within each decile might differ somewhat for women in expensive cities. An alternative flexible parametric approach to estimation, described in the Appendix, provides nearly identical inferences.

Our empirical findings are roughly consistent with theoretical predictions in Case 2. In that equilibrium example with Stone-Geary preferences, the responsiveness of labor supply to nonlabor income must be greater in inexpensive (lowproductivity) cities than expensive (highproductivity) cities.

\section{CONCLUSION}

We describe a simple model to demonstrate that the effects of wage and nonlabor income on labor supply typically differ by location. In particular, we show the derivative of the labor supply with respect to nonlabor income is independent of price only when labor supply takes a form based on an implausible separability condition.

Empirical evidence demonstrates that the effect of price on labor supply is not a simple "upor-down shift" that would be required to meet the separability condition in our key proposition. For example, among women with low nonlabor income, living in an inexpensive city is associated with higher labor force participation and longer work hours, whereas among women with high nonlabor income, living in an inexpensive city is associated with lower labor force participation and shorter work hours.
This work has a number of implications for empirical strategies in estimating labor supply and other policy research. First, our research makes clear that empirical work should never use crosssectional variation in wages to estimate parameters in labor supply models. We document significant differences for married women in quantity of labor supplied across cities that may have little connection with behavioral responses to crosssectional variation in wages.

Second, because labor supply elasticities vary by location, researchers must be careful in interpreting results based on instrumental variable (IV) strategies. For example, suppose an IV approach is used in which the IV is the price of coal. Variation in the price of coal arguably serves as an excellent source of wage variation in the coal industry, but the resulting estimates of the effect on labor supply would apply only for regions where the coal industry is a major employer. If local prices differ in those regions from other parts of the country, the estimated relationships will not be generalizable to the entire country.

Third, using a back-of-the-envelope example, we show that the evidence in Table 1 is consistent with the possibility that wage elasticities or labor supply (for married women) are quite different across cities. Notice that the Slutsky equation, in elasticity form, gives the relationship

$$
\varepsilon_{w}=\varepsilon_{w}^{H}+\left[\frac{w h}{N}\right] \varepsilon_{N},
$$

where $\varepsilon_{w}$ is the observed wage elasticity of supply, $\varepsilon_{w}^{H}$ is the corresponding Hicksian elasticity (reflecting the pure substitution effect), and $\varepsilon_{N}$ is the elasticity of labor supply with respect to nonlabor income. Now consider college-educated married women at the median level of nonlabor income. If we take as causal the relationship drawn in Figure 1, moving from the fourth to sixth deciles in income we would estimate a nonlabor income elasticity, $\varepsilon_{N}$, of -0.46 in the expensive cities and -0.29 in the inexpensive cities. Suppose that the Hicksian elasticity, $\varepsilon_{w}^{H}$, is 0.50 (and is the same in both cities). We estimate that for the average woman at the fourth decile $w h / N$ is 0.57 in inex- 
pensive cities and 0.61 in expensive cities. ${ }^{13}$ Thus, the uncompensated labor supply elasticity is more than a third higher in expensive cities than inexpensive cities, 0.33 versus 0.24 .

Fourth, as an example of an application to policy-related research, locational differences may occur in the response of female labor supply to changes in taxes. Changes in income taxes, for instance, would have different effects in different cities. A closely related implication centers on the analysis of social welfare policy. (Recall, for example, that wives of husbands with low earnings work less in more expensive cities.) We believe that further analysis of policy implications is warranted.

\section{REFERENCES}

Abbott, Michael and Ashenfelter, Orley. "Labour Supply, Commodity Demand and the Allocation of Time." Review of Economic Studies, 1976, 43(3), pp. 389-411.

Ashenfelter, Orley and Ham, John C. "Education, Unemployment, and Earnings.” Journal of Political Economy, 1979, 87(5), pp. 99-116.

Blundell, Richard and MaCurdy, Thomas. "Labor Supply: A Review of Alternative Approaches,” in Orley Ashenfelter and David Card, eds., Handbook of Labor Economics. Princeton, NJ: Princeton University Press, 1999, Vol. 3, pp. 1559-95.

Chen, Yong and Rosenthal, Stuart S. "Local Amenities and Life-Cycle Migration: Do People Move for Jobs or Fun?" Journal of Urban Economics, November 2008, 64(3), pp. 519-37.

DaVanzo, Julie; DeTray, Dennis N. and Greenberg, David H. "Estimating Labor Supply Response: A Sensitivity Analysis,” publication No. R-1372OEO. Santa Monica, CA: The RAND Corporation, 1973.

\footnotetext{
${ }^{13}$ In fact, the ratio of women's earnings to nonlabor household income (primarily men's earnings) is larger in expensive cities than in inexpensive cities at every decile.
}

Gabriel, Stuart A. and Rosenthal, Stuart S. "Quality of the Business Environment Versus Quality of Life: Do Firms and Households Like the Same Cities?" Review of Economics and Statistics, 2004, 86(1), pp. 438-44.

Haurin, Donald R. "The Regional Distribution of Population, Migration, and Climate.” Quarterly Journal of Economics, 1980, 95(2), pp. 293-308.

Killingsworth, Mark R. and Heckman, James J. "Female Labor Supply: A Survey," in Orley Ashenfelter and Richard Layard, eds., Handbook of Labor Economics. Princeton, NJ: Princeton University Press, 1986, Vol. 1, pp. 103-204.

Masters, Stanley H. and Garfinkel, Irwin. Estimating the Labor Supply Effects of Income Maintenance Alternatives. New York: Academic Press, 1977.

Pencavel, John. "Labor Supply of Men: A Survey," in Orley Ashenfelter and Richard Layard, eds., Handbook of Labor Economics. Princeton, NJ: Princeton University Press, 1986, Vol. 1, pp. 3-102.

Roback, Jennifer. "Wages, Rents, and the Quality of Life." Journal of Political Economy, 1982, 90(6), pp. 1257-78.

Ruggles, Steve; Sobek, Matthew; Alexander, Trent; Fitch, Catherine; Goeken, Ronald; Hall, Patricia; King, Miriam and Ronnander, Chad. Integrated Public Use Microdata Series: Version 4.0 (machinereadable database). Minneapolis, MN: Minnesota Population Center, 2008; usa.ipums.org/usa/. 


\section{APPENDIX}

The empirical inferences in Table 1 are based on an entirely nonparametric approach. We divided our sample into 10 nonlabor income deciles and compared labor supply across women within each of these cells. Our primary finding is that for women in low nonlabor income deciles, the labor supply is lower in expensive cities than in inexpensive cites, whereas for women in high nonlabor income deciles, labor supply is higher in expensive cities than in inexpensive cities.

Here we present a flexible parametric approach that leads to this same inference. We estimate labor supply regressions with the independent variables age (entered as 21 dummy variables for each age, 30 to 50 years inclusive) and nonlabor income (entered as a fourth-order polynomial). We estimate regressions-separately for high school-educated women and college-educated women, as well as for each labor supply variable (employment and hours worked)—using the sample of women from the expensive cities. We similarly estimate corresponding regressions for the sample of women from the inexpensive cities. Then for each woman $i$ who lives in the expensive cities, we estimate the outcome of interest $\hat{y}_{1 i}$ (e.g., "predicted" employment, or "predicted" hours worked) using the regression parameter from the expensive city, and similarly estimate $\hat{y}_{0 i}$ using regression parameters from the inexpensive city. Finally, we form the estimated gap,

$$
\hat{\Delta}_{i}=\hat{y}_{1 i}-\hat{y}_{0 i},
$$

for each individual. Notice that this last quantity is the "impact of the treatment on the treated," where the "treatment" is location in an expensive city rather than an inexpensive city.

To summarize findings in a manner comparable to Table 1, we aggregate estimates into deciles of nonlabor income. Results are presented in Table A1. Bootstrapped standard errors using 999 replications are reported in parentheses. ${ }^{14}$

\footnotetext{
${ }^{14}$ Bootstrap procedure in this case involves 999 replications of generating a random sample with replacement from the original dataset and estimating the parameter of interest for that sample. After 999 replications, we have a sampling distribution of the parameter estimate. The standard deviation of that distribution is the standard error of the parameter estimate.
} 


\section{Table A1}

\section{Differences in Annual Hours and Participation Rates Between Expensive and Inexpensive Locations by Nonlabor Income Deciles, Parametric Approach}

\begin{tabular}{|c|c|c|c|c|}
\hline \multirow[b]{2}{*}{ Nonlabor income decile } & \multicolumn{2}{|c|}{$\begin{array}{l}\text { Women with a } \\
\text { high school diploma }\end{array}$} & \multicolumn{2}{|c|}{$\begin{array}{l}\text { Women with a } \\
\text { college degree }\end{array}$} \\
\hline & $\begin{array}{l}\text { Change in } \\
\text { annual hours }\end{array}$ & $\begin{array}{c}\text { Change in } \\
\text { participation rates }\end{array}$ & $\begin{array}{c}\text { Change in } \\
\text { annual hours }\end{array}$ & $\begin{array}{c}\text { Change in } \\
\text { participation rates }\end{array}$ \\
\hline 1 & $\begin{array}{l}-128.7 \\
(22.04)\end{array}$ & $\begin{array}{l}-0.034 \\
(0.0110)\end{array}$ & $\begin{array}{l}-118.1 \\
(34.23)\end{array}$ & $\begin{array}{l}-0.027 \\
(0.0143)\end{array}$ \\
\hline 2 & $\begin{array}{l}-93.4 \\
(12.42)\end{array}$ & $\begin{array}{c}-0.021 \\
(0.0066)\end{array}$ & $\begin{array}{l}-72.5 \\
(17.76)\end{array}$ & $\begin{array}{l}-0.016 \\
(0.0079)\end{array}$ \\
\hline 3 & $\begin{array}{l}-68.6 \\
(11.10)\end{array}$ & $\begin{array}{c}-0.013 \\
(0.0059)\end{array}$ & $\begin{array}{l}-36.6 \\
(16.07)\end{array}$ & $\begin{array}{l}-0.002 \\
(0.0074)\end{array}$ \\
\hline 4 & $\begin{array}{l}-47.1 \\
(10.82)\end{array}$ & $\begin{array}{c}-0.005 \\
(0.0056)\end{array}$ & $\begin{array}{c}-9.5 \\
(15.23)\end{array}$ & $\begin{array}{c}0.009 \\
(0.0071)\end{array}$ \\
\hline 5 & $\begin{array}{l}-28.1 \\
(10.26)\end{array}$ & $\begin{array}{c}0.001 \\
(0.0056)\end{array}$ & $\begin{array}{c}19.1 \\
(14.59)\end{array}$ & $\begin{array}{c}0.021 \\
(0.0066)\end{array}$ \\
\hline 6 & $\begin{array}{l}-2.1 \\
(11.15)\end{array}$ & $\begin{array}{l}0.01 \\
(0.0056)\end{array}$ & $\begin{array}{l}46.5 \\
(14.18)\end{array}$ & $\begin{array}{c}0.032 \\
(0.0066)\end{array}$ \\
\hline 7 & $\begin{array}{l}23.8 \\
(12.73)\end{array}$ & $\begin{array}{l}0.019 \\
(0.0061)\end{array}$ & $\begin{array}{l}76.5 \\
(14.59)\end{array}$ & $\begin{array}{l}0.045 \\
(0.0071)\end{array}$ \\
\hline 8 & $\begin{array}{c}55.3 \\
(15.28)\end{array}$ & $\begin{array}{c}0.030 \\
(0.0077)\end{array}$ & $\begin{array}{l}108.6 \\
(17.27)\end{array}$ & $\begin{array}{c}0.058 \\
(0.0082)\end{array}$ \\
\hline 9 & $\begin{array}{c}87.5 \\
(20.48)\end{array}$ & $\begin{array}{c}0.042 \\
(0.0102)\end{array}$ & $\begin{array}{l}143.5 \\
(20.89)\end{array}$ & $\begin{array}{c}0.075 \\
(0.0099)\end{array}$ \\
\hline 10 & $\begin{array}{l}81.6 \\
(38.06)\end{array}$ & $\begin{array}{l}0.036 \\
(0.0207)\end{array}$ & $\begin{array}{l}123.1 \\
(30.26)\end{array}$ & $\begin{array}{l}0.066 \\
(0.0151)\end{array}$ \\
\hline
\end{tabular}

NOTE: Authors' calculations, based on 1990 PUMS data. The sample consists of all married, white, non-Hispanic women between the ages of 30 and 50 inclusive. The covariates are nonlabor income and age. Using a fourth-order polynomial, we use the sample of women from expensive cities to estimate the outcome of interest, which we denote $\hat{y}_{1 i}$ for the $i$ th women. Using the sample of women from inexpensive cities, we estimate parameters for a fourth-order polynomial and then evaluate the function using the covariates of women from the expensive city sample, which we denote $\hat{y}_{0 i}$ for the $i$ th women. We then form the parameter for the "impact of treatment on the treated" as $\hat{\Delta}_{i}=\hat{y}_{1 i}-\hat{y}_{0 i}$. We then aggregate estimates into deciles of nonlabor income. Bootstrapped standard errors using 999 replications are reported in parentheses. 
